\title{
Physico Chemical Assessment and Comparison of Quality of Underground Water for Drinking Purpose at Periodic Interval in the Village of Srikurmam, Gara Mandal in Srikakulam District, Andhra Pradesh, India
}

\author{
VADDI DHILLESWARA RAO', MUSHINI VENKATA SUBBA RAO'* \\ AND M.P.S. MURALI KRISHNA ${ }^{2}$ \\ 1Department of Chemistry, G.M.R Institute of Technology, Rajam-532 127, \\ Srikakulam District, Andhra Pradesh, India. \\ ${ }^{2}$ Department of Chemistry, Andhra Polytechnic, Kakinada - 533003, Andhra Pradesh, India.
}

http://dx.doi.org/10.12944/CWE.9.3.32

(Received: September 11, 2014; Accepted: October 19, 2014)

\begin{abstract}
Safe drinking water is essential to the protection of public health and well-being of citizens. Clean safe and adequate fresh water is vital to the survival of all living organisms. Drinking water affects the health of human beings due to the presence of various chemical constituents. Therefore, every person should have required the minimum knowledge of quality of drinking water.

Ground water is the one of the major sources of water for drinking, agricultural and industrial needs. The subject of the quality of water in village of Srikurmam in Gara mandal of Srikakulam District, Andhra Pradesh is taken up for the study. An attempt is made to investigate the physico-chemical parameters of ground water on seasonal base and its comparison. The results in this presentation are reported and comparison on the seasonal base like June 2011, July 2012 , July 2013 and in the month of May 2014. The results obtained are related to electrical conductivity, pH, Turbidity, Total Dissolved Solids, Total Hardness, Calcium and Magnesium Hardness, Chlorides, Alkalinity, Fluorides, Nitrites, Phosphates, Phenol, Metals like Sodium, Potassium, Iron, Zinc, Cadmium, Cobalt, Nickel, Lead and Copper. The results obtained are compared with standards of WHO and BIS and assessing the quality of ground water for drinking purposes through Water Quality Index (WQI). Finally, the results indicate that the water at Srikurmam is not fit for drinking without using a standard purification method.
\end{abstract}

Key words: Quality of underground water, Srikurmam, Srikakulam and Chemical constituents.

\section{INTRODUCTION}

Water is a natural resource that sustains the necessary needs of all living creatures. It is not only for drinking and it plays a vital role in various sectors as in the form of an essential Engineering material. It is required for sustaining all forms of life, food production, economic development of industry and agriculture

The main resource of fresh water is the groundwater ${ }^{1}$, which is commonly used for domestic, irrigation and industrial purposes. Ground water is the major source of drinking water in both urban and rural India. It is an important source of drinking water, but now a days, it is polluted in most areas due to increased human population, growth of industrial activities, dumping of industrial waste, improper disposal of garbage, use of fertilizers in agriculture and manmade activities ${ }^{2}$. Physical, chemical and biological characteristics determine the quality of water. Hence, it becomes essential to ensure the quality of groundwater to utilize it for various purposes.

The domestic, agricultural activities mostly depend on the groundwater in majority areas, and hence it is known to the importance of groundwater quality ${ }^{3-5}$. The quality of water and its environment is subjective to the geologic formation of an area 
and mostly, the groundwater contains more mineral contents than the surface water. It is for this reason that the groundwater movement is slow and hence, longer contacts time with the sediments and the hydrologic conditions have a significant role ${ }^{6}$ in the change of groundwater quality over a period.

The monitoring of water quality is one of the major tools for sustainable development and provides important information for water management ${ }^{7}$. The quality of water is vital concern for humanity since it is directly linked with human welfare. Therefore, monitoring the quality of water is one of the essential issues of drinking water management ${ }^{8}$. The quality of underground water in Srikurmam, Gara Mandal of Srikakulam District, Andhra Pradesh is observed closely and continously at periodic interval. Thus, in this research work an attempt has been made to assess the physical and chemical parameters of ground water at Srikurmam.

\section{EXPERIMENTAL}

\section{Study area}

Srikurmam village is located approximately 13 kilometers east of Srikakulam town near Bay of Bengal and is in the Gara Mandal of Srikakulam District, Andhra Pradesh, India. Srikurmam is located at latitude of $18^{\circ} 16^{\prime} \mathrm{N}$, longitude of $84^{\circ} 1^{\prime} \mathrm{E}$ and an altitude of 17 meters (59 feet).

\section{Water sampling}

The groundwater samples are collected as per the standard manner ${ }^{4}$ in the month of June 2011, July 2012, July 2013 and of May 2014. After each sample is collected, they are analyzed immediately for various parameters or preserved safely by taking care with suitable standard precautionary methods to avoid deterioration/alteration. All the water samples are collected in 2 Litres plastic bottles that were washed and double rinsed with distilled water before sampling. The list of sample collection places in Srikurmam is given in the Table 1.

\section{Instruments used}

The following instruments are used to analyze various constituents present in ground water samples. Atomic Absorption Spectrometer (AAS) (PerkinElmer 400), UV-Visible Double beam Spectrophotometer(Model AU - 2701,
Systronics), Digital pH meter (Model 335, Systronics), Nefleometer (Model 132, Systronics), Digital Conductometer(Model 306, Systronics), Micro processor based bunch $\mathrm{P}^{\mathrm{H}}$ / Ion meter, Cyber scan 2100, Eutech instruments (USA) with fluoride sensitive electrode.

\section{Chemicals used}

All the Chemicals used are of Analytical Reagent Grade (Merck, BDH and Qualigens) and the solutions are prepared by using triply distilled water and, water without carbon dioxide is used when required. The following solutions are used for analysis and wherever standard solutions are required, for this the standardization methods ${ }^{9}$ are followed. The following list of chemicals are used in this research work such as Potassium hydrogen phthalate, Potassium hydrogen phosphate, Potassium dihydrogen phosphate, Calcium Carbonate, EDTA, $\mathrm{Na}_{2} \mathrm{CO}_{3}, \mathrm{HCl}, \mathrm{NaCl}, \mathrm{AgNO}_{3}$, Sodium oxalate, Potassium permanganate, Ferrous Ammonium Sulphate, $\mathrm{K}_{2} \mathrm{Cr}_{2} \mathrm{O}_{7}$ APDC (Ammonium 1- pyrolidiene dicarbomate), MIBK (Methyl Isobutyl ketone) and concentrated $\mathrm{HNO}_{3}, \mathrm{Hypo}, 10 \% \mathrm{BaCl}_{2}$, $10 \% \mathrm{KI}, 1000 \mathrm{ppm}$ of fluoride and Nitrite solution, stock phenol solution, 4-aminoantipyrine, Potassium ferricyanine, chloroform, Borax buffer, Ammonium chloride-ammonium hydroxide buffer solution, TISAB Buffer, $\mathrm{AgNO}_{3}$ - Nitric acid reagent, Vanadate molybdate reagent, $0.5 \%$ Sulphanalamide reagent and indicators of phenolphthalein, methyl orange, EBT, Muroxide, $\mathrm{K}_{2} \mathrm{CrO}_{4}$ and $1 \%$ Starch.

\section{Procedure of assessment of various constituents in water}

For estimation of various constituents present in the groundwater like $\mathrm{pH}$, Electrical Conductivity(EC), Turbidity, Total Dissolved Solids(TDS), Alkalinity, Total Hardness(TH), Ca and $\mathrm{Mg}$ Hardness, Fluoride $\left(\mathrm{F}^{-}\right)$, Chloride $\left(\mathrm{Cl}^{-}\right)$, Nitrite $\left(\mathrm{NO}_{2}{ }^{-}\right)$, Sulphate, Phosphate, Phenol \& metals like Sodium( $\mathrm{Na})$, Potassium(K), Iron( $\mathrm{Fe}), \mathrm{Zinc}(\mathrm{Zn})$, Cadmium(Cd), Nickel(Ni), Cobalt(Co) and Lead(Pb) are estimated by following standard methods ${ }^{10}$.

\section{RESULTS AND DISCUSSIONS}

Based on the results obtained in Periodic interval [Table 2, 3 and 3(a)] the analyzed parameters are compared with the values of $\mathrm{WHO}^{11}$ and $\mathrm{BIS}^{12}$ 
to know the quality of water. In all periodic intervals (June 2011, July 2012, July 2013 and in the month of May 2014) all the parameters are analysed and compared. It is identified that they maintains almost nearer values in the respective interval times. Many parameters do not match desired limits of potable parameters as per standard guidelines of $\mathrm{WHO}^{11}$ and $\mathrm{BIS}^{12}$. From the obtained values, graphs (Figure1, 2, 3 and 4) are drawn for some of the parameters with their desirable limits for its comparison.

Here the Water Quality Index (WQI) ${ }^{13}$ values has been calculated and reported based on the results obtained in the samples for the year 2014 to evaluate the suitability of ground water quality for potable purpose. The same procedure was also implemented to the samples that are collected in the years 2011, 2012 and 2013. For calculation of WQI, the following four steps have been taken into account. In the first step, each of the nine analyzed parameters has been assigned a weight (wi) according to its relative importance in the overall quality of water for drinking purposes Table 4 . In the second step, the relative weight (Wi) is calculated as per the established ${ }^{13-15}$ method as follows.

Relative weight $(\mathrm{Wi})=\frac{w i}{\sum_{i=1}^{n} w i} \mid$

Here 'Wi' is the relative weight, 'wi' is the weight of each parameter and ' $n$ ' is the number of parameters.

Table 1: List of sample collection sites

\begin{tabular}{lll}
\hline S no. Location of sample & Source \\
\hline 1 & Brahmin Street & Bore Water \\
2 & Kurmanatha Temple opposite & Bore Water \\
3 & Vyshnavi Street & Bore Water \\
4 & Near Bus Stand & Bore Water \\
5 & Secondary Government School & Bore Water \\
6 & Karnala Street & Bore Water \\
7 & Karnala Street & Well Water \\
8 & Kandra Street & Bore Water \\
9 & Market Street & Bore Water \\
10 & Devara Street & Bore Water \\
11 & Segidipeta & Bore Water \\
12 & Indiranagar colony & Bore Water \\
13 & Velama Street & Well Water \\
14 & Panchayati office & Well Water \\
15 & Bankers colony(Pratap house) & Bore Water \\
\hline
\end{tabular}

In the third step a quality rating scale (Qi) for each parameter is calculated by following equation; Qi $=(\mathrm{Ci} / \mathrm{Si}) \times 100$, here ' $\mathrm{Ci}$ ' is the concentration of each chemical parameter in each water sample in $\mathrm{mg} / \mathrm{L}$ and ' $\mathrm{Si}$ ' is the standard value according to the Guide lines of $\mathrm{WHO}^{16}$ per each chemical parameter [Table 4]. In the fourth step the sub index (Sli) of each chemical parameter is estimated by using the equation

Sli $=$ Wi $\times$ Qi. The overall Water Quality Index was calculated by adding together each sub index values of each water samples as follows;

$\mathrm{WQI}=\sum S l i$

Based on the results of obtained [Table 5] Water Quality Index from the samples and these values are compared with the standard [Table 5] WQI values ${ }^{17,18}$ for human consumption. It clearly

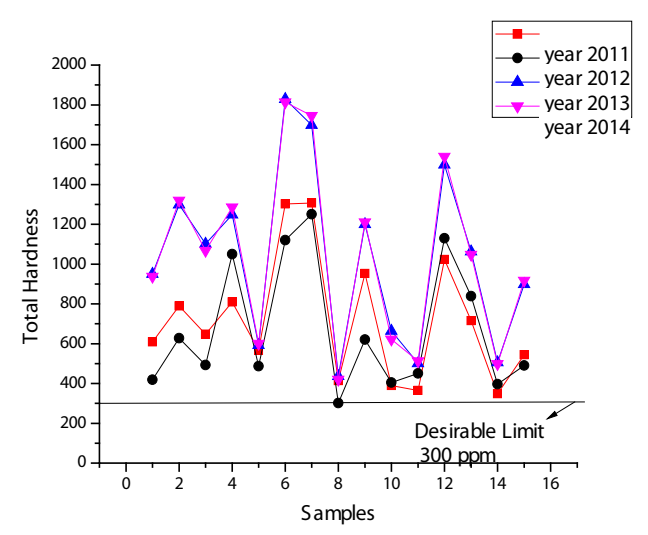

Fig. 1: Plot of Hardness Vs samples

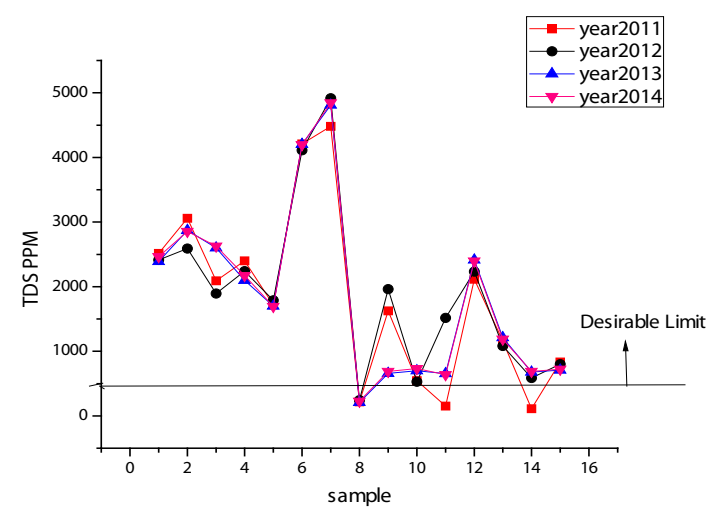

Fig. 2: Plot of Total Dissolved Solids Vs samples 


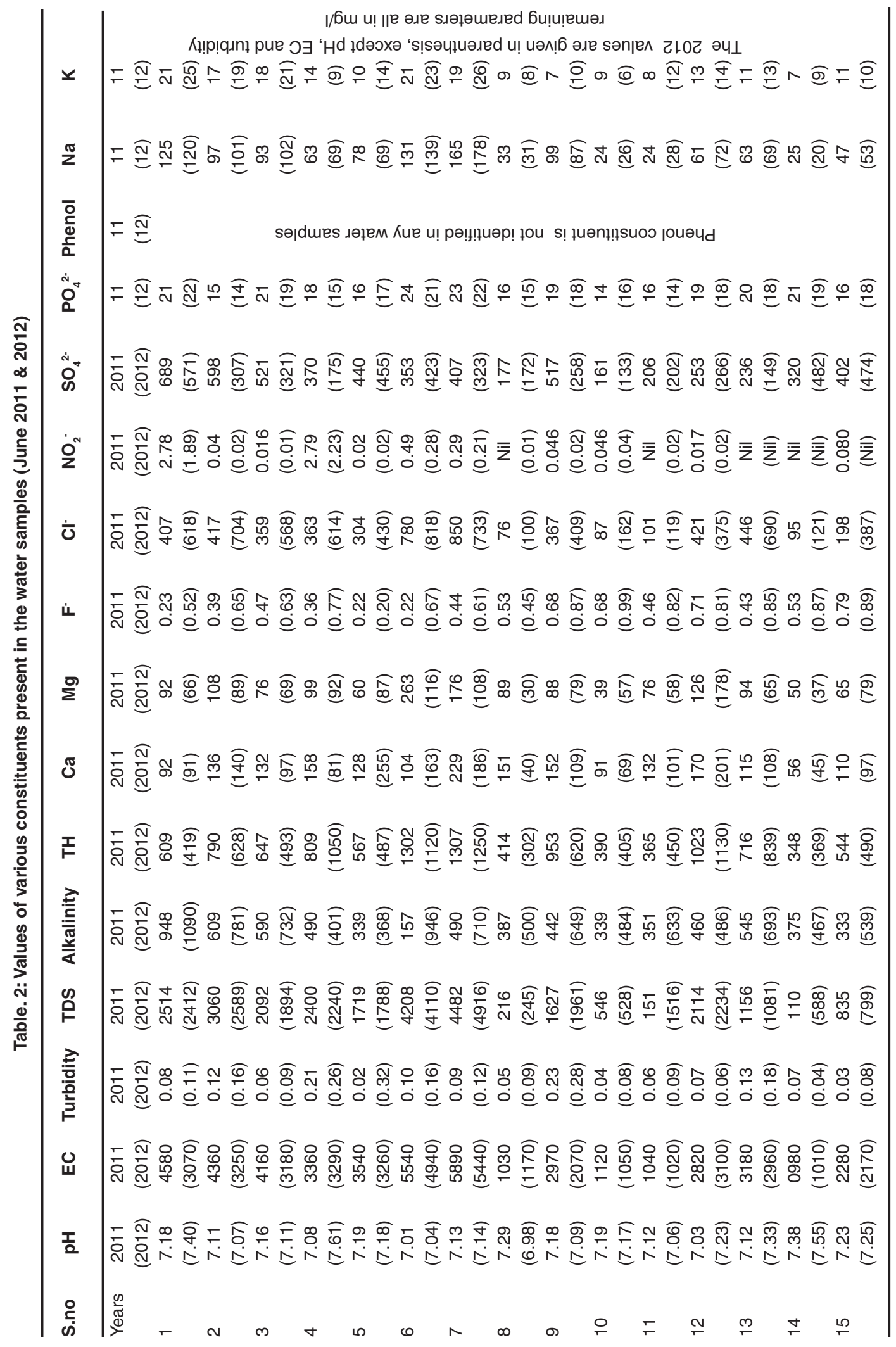




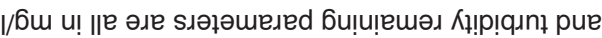

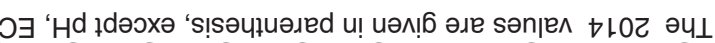

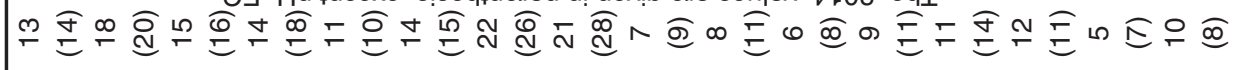

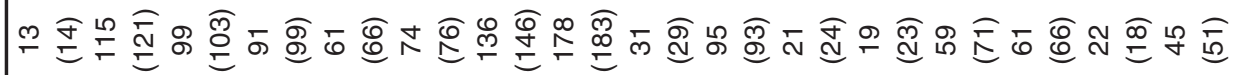

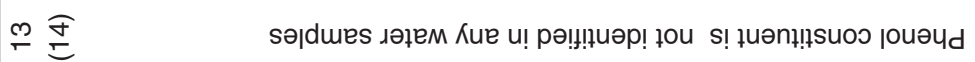

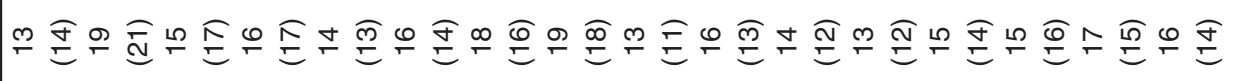

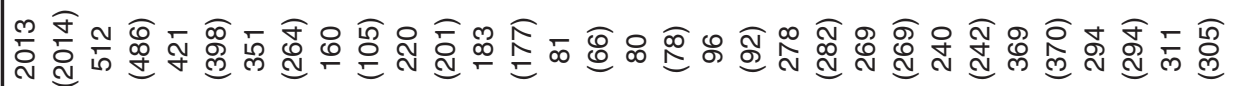

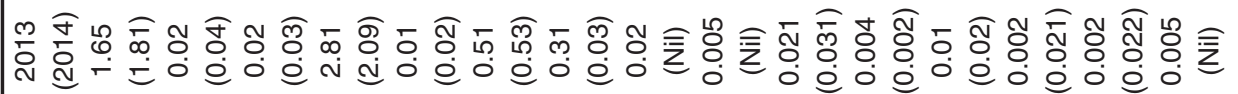

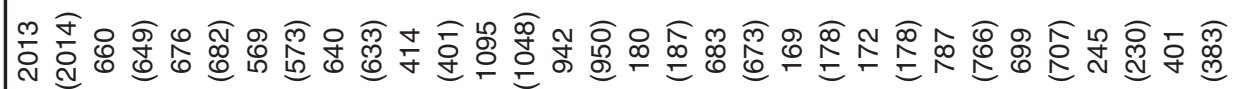

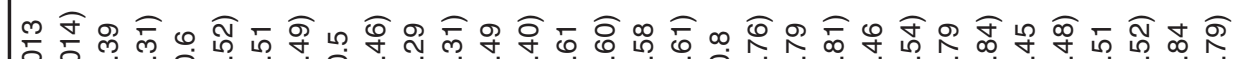

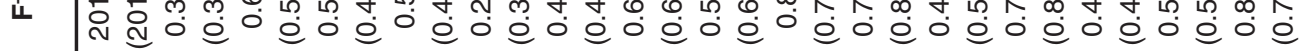

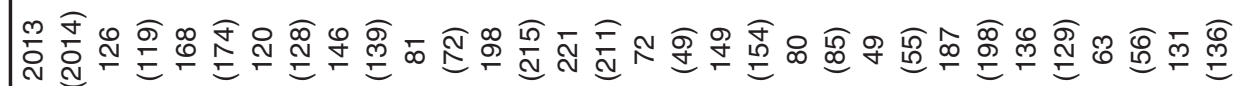

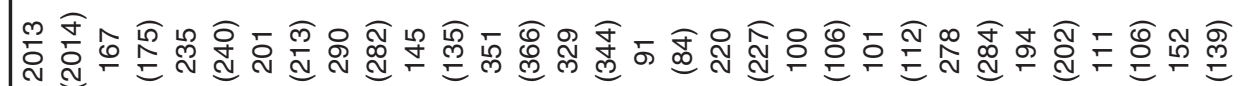

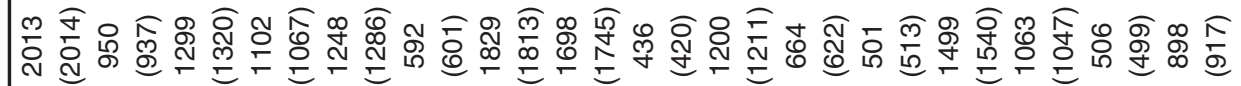

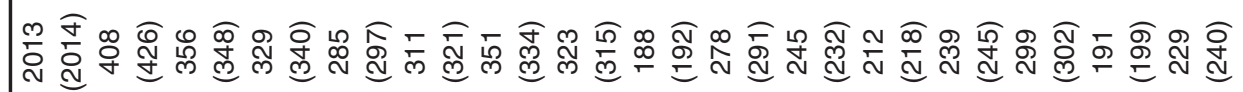

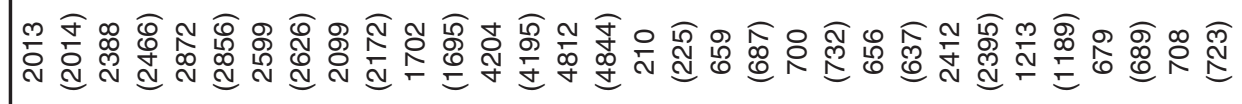

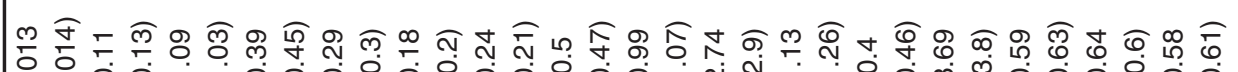
a d o 0

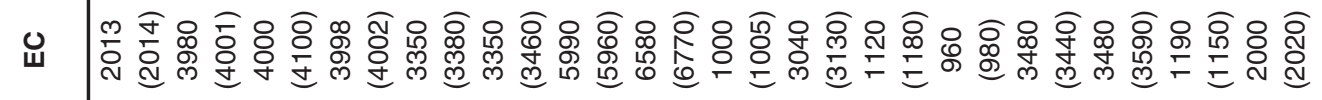

I 운

듬

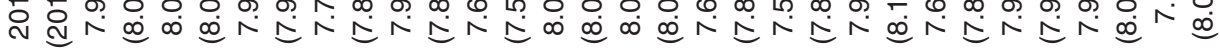
$\stackrel{2}{\circ}$ 


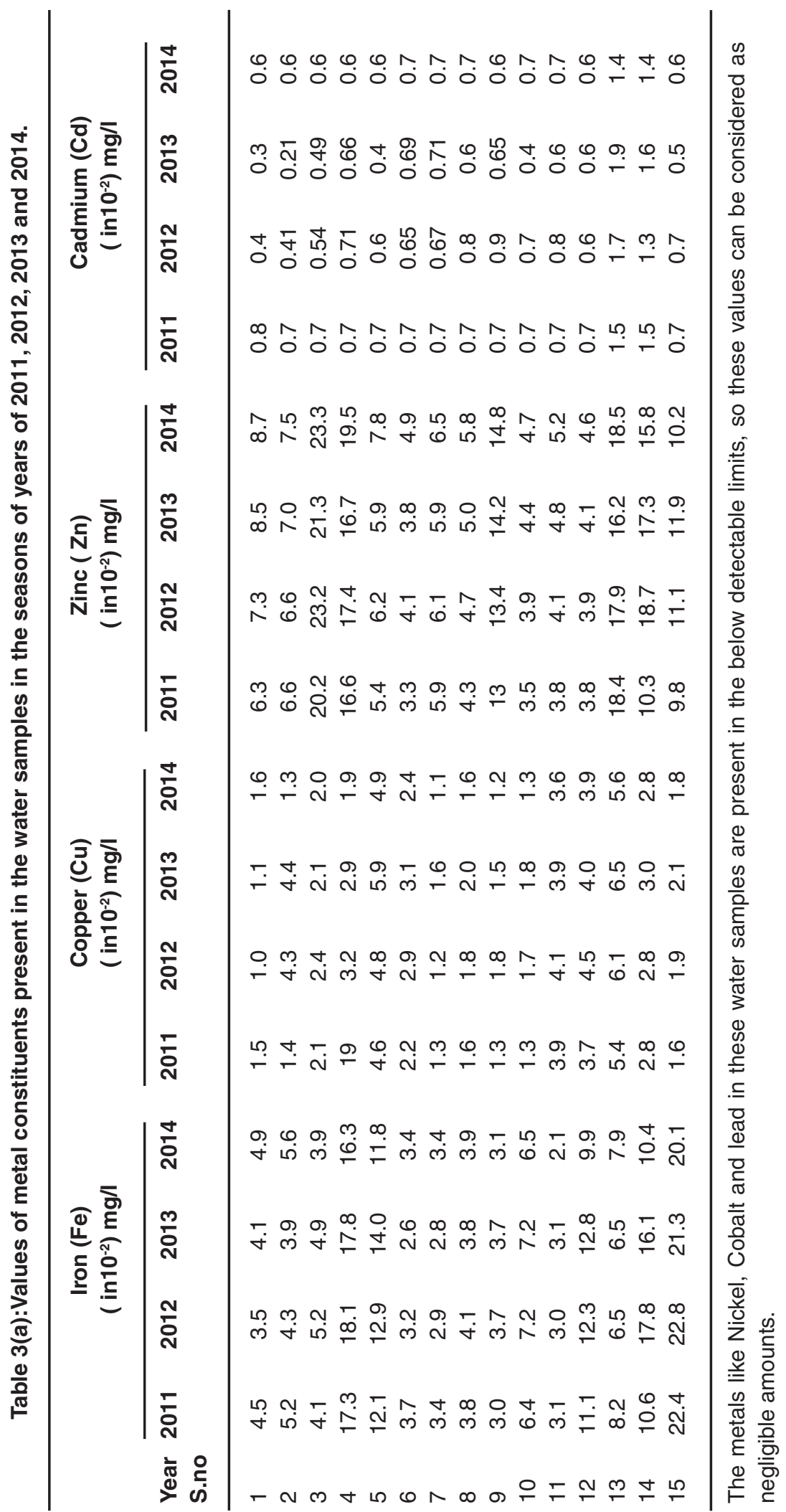


indicates that the underground water at research sites in most of the areas in Srikurmam is not fit for drinking purposes without any purification. Therefore, based on the overall results the underground water at Srikurmam in almost all areas is not suitable for drinking.

Table. 4: Chemical Parameters, weight (wi), WHO Standards and calculated weight (Wi) for each Parameter

\begin{tabular}{llccc}
\hline S.No & Chemical Parameter & Weight(wi) & WHO Standards(Si) & Relative weights (Wi) \\
\hline 1 & TDS & 5 & 500 & 0.16666 \\
2 & Total Hardness & 5 & 300 & 0.16666 \\
3 & Chloride & 4 & 250 & 0.13333 \\
4 & sulphate & 3 & 250 & 0.1 \\
5 & Calcium & 2 & 75 & 0.06666 \\
6 & Magnesium & 2 & 50 & 0.06666 \\
7 & Fluoride & 4 & 1.5 & 0.13333 \\
8 & Sodium & 4 & 200 & 0.13333 \\
9 & Pottasium & 1 & 12 & 0.03333 \\
& & 5 wi $=30$ & & \\
\hline
\end{tabular}

Table. 5: Water quality Index of each ground water sample at Srikurmam

\begin{tabular}{|c|c|c|c|c|c|c|c|c|c|c|}
\hline \multicolumn{2}{|c|}{ S.No TDS(Sli) } & \multirow{2}{*}{$\begin{array}{c}\text { TH(Sli) } \\
52.05\end{array}$} & \multirow{2}{*}{$\begin{array}{c}\mathbf{C l} \text { (Sli) } \\
34.61\end{array}$} & \multirow{2}{*}{$\frac{\mathrm{SO}_{4}{ }^{2-}(\mathrm{Sli})}{19.44}$} & \multirow{2}{*}{$\frac{\mathrm{Ca}^{2+}(\mathbf{S l i})}{15.55}$} & \multirow{2}{*}{$\frac{\mathbf{M g}^{2+}(\mathrm{Sli})}{15.86}$} & \multirow{2}{*}{$\begin{array}{c}\mathbf{F}-(\mathbf{S l i}) \\
2.75\end{array}$} & \multirow{2}{*}{$\begin{array}{c}\mathrm{Na}^{+}(\mathrm{Sli}) \\
8.06\end{array}$} & \multirow{2}{*}{$\frac{\mathbf{K}^{+}(\mathbf{S l i})}{5.55}$} & \multirow{2}{*}{$\begin{array}{c}\text { WQI } \\
236.0\end{array}$} \\
\hline 1 & 82.2 & & & & & & & & & \\
\hline 2 & 95.2 & 73.33 & 36.37 & 15.92 & 21.33 & 23.19 & 4.62 & 6.86 & 4.44 & 281.2 \\
\hline 3 & 87.53 & 59.27 & 30.55 & 10.56 & 18.93 & 17.06 & 4.35 & 6.59 & 4.99 & 239.8 \\
\hline 4 & 72.4 & 71.44 & 33.75 & 4.2 & 25.06 & 18.53 & 4.08 & 4.39 & 2.77 & 236.6 \\
\hline 5 & 56.5 & 33.38 & 21.38 & 8.04 & 11.99 & 9.59 & 2.75 & 5.06 & 4.16 & 152.8 \\
\hline 6 & 139.83 & 100.7 & 55.89 & 7.08 & 32.53 & 28.66 & 3.55 & 9.73 & 7.22 & 385.2 \\
\hline 7 & 161.46 & 96.94 & 50.66 & 2.64 & 30.57 & 28.13 & 5.33 & 12.19 & 7.77 & 395.6 \\
\hline 8 & 7.5 & 23.33 & 9.973 & 3.12 & 7.46 & 6.53 & 5.42 & 1.53 & 2.49 & 67.35 \\
\hline 9 & 22.9 & 67.27 & 35.89 & 3.68 & 20.17 & 20.53 & 6.75 & 6.19 & 3.05 & 186.4 \\
\hline 10 & 24.4 & 34.55 & 9.49 & 11.28 & 9.42 & 11.33 & 7.19 & 1.59 & 2.22 & 111.4 \\
\hline 11 & 21.23 & 28.5 & 9.49 & 10.76 & 9.95 & 7.33 & 4.79 & 1.53 & 3.05 & 96.63 \\
\hline 12 & 79.83 & 85.55 & 40.85 & 9.68 & 25.24 & 26.39 & 7.46 & 4.73 & 3.88 & 283.6 \\
\hline 13 & 39.63 & 58.16 & 37.7 & 14.8 & 17.95 & 17.19 & 4.26 & 4.39 & 3.05 & 197.1 \\
\hline 14 & 22.96 & 27.72 & 12.26 & 11.76 & 9.42 & 7.46 & 4.62 & 1.19 & 1.94 & 99.33 \\
\hline 15 & 24.1 & 50.94 & 20.42 & 12.2 & 12.35 & 18.13 & 7.02 & 3.39 & 2.22 & 150.7 \\
\hline \multicolumn{11}{|c|}{ Standard WQI values for water to human consumption } \\
\hline \multicolumn{3}{|c|}{ WQI Range } & \multicolumn{3}{|c|}{ Type of Water } & & & & & \\
\hline \multicolumn{3}{|c|}{$<50$} & \multicolumn{3}{|c|}{ Excellent Water } & & & & & \\
\hline \multicolumn{3}{|c|}{$50.1-100$} & \multicolumn{3}{|c|}{ Good Water } & & & & & \\
\hline \multicolumn{3}{|c|}{$100.1-200$} & \multicolumn{3}{|c|}{ Poor Water } & & & & & \\
\hline \multicolumn{3}{|c|}{$200.1-300$} & \multicolumn{3}{|c|}{ Very Poor Water } & & & & & \\
\hline \multicolumn{3}{|c|}{$>300.1$} & \multicolumn{3}{|c|}{ Unfit for Water } & & & & & \\
\hline
\end{tabular}




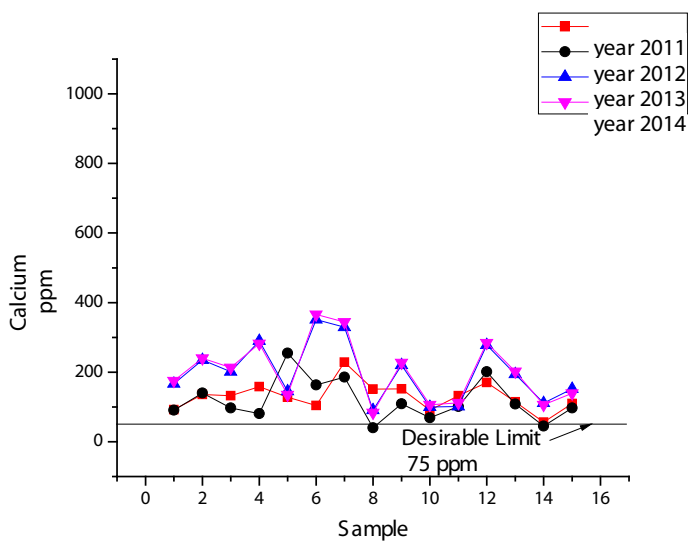

Fig. 3: Plot of Calcium content Vs samples

Further, an attempt is made to know the possibility of removal of hardness from the samples by using a conventional method such as boiling. It is not helpful in any manner. This clearly indicates that the rate of decreasing of hardness is very less in the chosen samples and the underground water in Srikurmam has a characteristic property of more permanent hardness than temporary hardness. In addition, one more attempt is made to remove the excess amounts from the various constituents present in the water; the water is subjected to Reverse Osmosis (RO) process. After treatment by $\mathrm{RO}$, the treated water samples are analyzed and the results obtained clearly indicate that maximum excess amounts are eliminated by $\mathrm{RO}$ technique; it indicates that the water in Srikurmam is treated to make it suitable for drinking. Hence, the overall

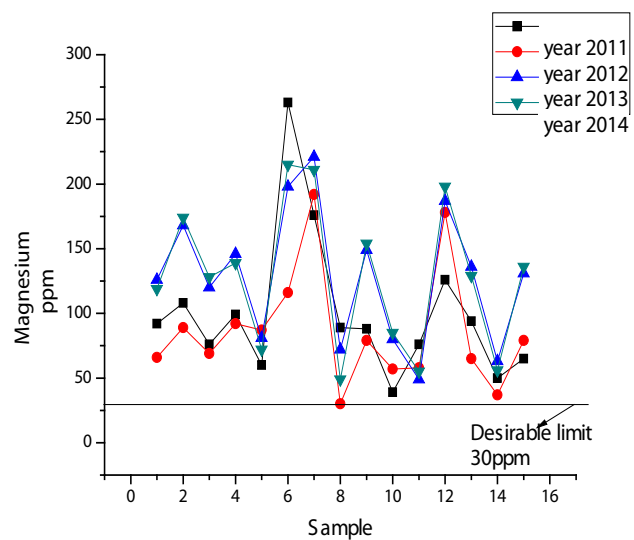

Fig. 4: Plot of Magnesium content Vs samples

results indicate that the water at Srikurmam is not fit for drinking without using an established purification method.

After thorough observations of the study area and physical chemical analysis of groundwater samples at Srikurmam, the causes of contamination of the ground water may be either because of seepage of sewage and sullage or of natural geological conditions. In addition to this, the wastewater from different sources such as kitchens, septic tanks and cesspits is discharged in to drainage canals. Unfortunately, the drainage canals are not properly constructed and maintained. As a result, there is an every possibility of seepage of sewage and sullage to the ground water and it will pollute the underground water in the areas under study.

\section{REFERENCES}

1. Sudharsanam, A., BabuAbraham, A., \& Shanthakumar, S. Assessment of physicochemical characteristics of groundwater. A case study, Int Env Health Eng. 2: 34 - 37 (2013)

2. Nareshkumar., SukhvinderSingh, P., kritika, R., Ashish, P., \& Amitkumar. To study the Physico - Chemical Properties and Bacteriological examination of step well water from Majhwar region in Distt. Mandi of Himachal Pradesh, India. International Journal of Current Research, 5: 4118-4123 (2013).

3. Chhaya, V. W., Sudarshan, J., Kokate., Haribhau, R., Aher., \& Shashikant. R.
K. Physico-Chemical Analysis Of Ground Water In Pravara Area, District Ahmednagar, Maharashtra. Rasayan J. Chem, 2: 234-242 (2009).

4. Reza, R., \& Singh, G., Physico - Chemical analysis of groundwater in Angul - Talcher Region of Orissa, India. Journal of American Science, 5: 53-58 (2009).

5. Kalshetty, B. M., Sheth, R. C., Hiremath, P. S., \& Kalashetti, M. B. Physicochemical analysis of ground water samples of Jamkhandi town in Bagalkot district, Karnataka state. Int $J$ Chem Sci, 9: 412 - 420 (2011).

6. Shahnawaz, M., \& Singh, K. M., Groundwater quality of piro and jagdishpur blocks of 
Bhojpur city: A middle gangatic plain. Int $J$ Pharm Qual Assur, 1: 9 - 13 (2009).

7. Vasanthavigar, M. Characterization and quality assessment of groundwater with a special emphasis on irrigation utility: Thirumanimuttar sub-basin, Tamilnadu, India. Arabian journal of Geosciences, 1; 1-14 (2010).

8. Shama, S., IffatNaz., Mohammadlshtiaq, A., \& Safia, A. Monitoring of Physico - Chemical and Microbiological Analysis of Under Ground Water Samples of District KallarSyedan, Rawalpindi, Pakistan. Research Journal of Chemical sciences, 1: 24-30 (2011).

9. Jeffery, G.H., Bassett, J., Mendham, J., \& Denney, R.C. Vogel's textbook of quantitative chemical analysis, Pearson education (Singapore) Pvt. Ltd, $5^{\text {th }}$ Edition, Revised (1989).

10. Subba Rao, M. V., Dhilleswararao, V., \& Andtrews, B. S. A. Assessment of Quality of Drinking Water at Srikurmam in Srikakulam District, Andhra Pradesh, India. Int Res J Environment Sci, 1: 13-20 (2012).

11. World Health Organization, "Guidelines for Drinking - Water Quality," 3rd Edition, World Health Organization (WHO), Geneva, Switzerland. WHO (2004).

12. Bureau of Indian Standards, Drinking Water
- Specification; September, 1991.

13. Gebrehiwot, A. B., Tadesse, N., \& Jigar, E. Application of water quality index to assess suitability of groundwater quality for drinking purposes in Hantebet Watershed, Tigray, Northern Ethiopia, ISASB. J Food Agri Sci, 1: 22- 30 (2011).

14. Brown, R. M., McCleiland, N. J., Deininger, R. A., \& O'Connor, M. F., A water quality index -crossing the psychological barrier Proc. Int Conf Water Poll Res ( Jerusalem, Jenkis, S.H. ed.) 6: 787-797 (1972).

15. Horton, R. K. An index number system for rating water quality, $J$ Water Pollut Control Fed, 37: 300- 305 (1965).

16. World Health Organization, "Guidelines for Drinking-Water Quality," 3rd Edition, World Health Organization (WHO), Geneva, Switzerland. WHO (2004).

17. Sahu, P., \& Sikdar, P. K. Hydrochemical framework of the aquifer in and around East Kolkata wetlands, West Bengal, India. Environ Geol, 55: 823-835 (2008).

18. Ramakrishnaiah, C. R., Sadashivaiah, C., \& Ranganna, G. Assessment of Water Quality Index for the Groundwater in TumkurTaluk, Karnataka State, India. E J Chem, 6: 523530 (2009). 